\title{
Gastronomi Festivali Tercihinde Ziyaretçilerin Memnuniyet ve Bağlılık Düzeylerini Etkileyen Faktörler: Ege Bölgesi Örneği ${ }^{a}$ Elif ASLAN ${ }^{b, c}$, Aylin AKOĞLUd, Serkan ŞENGÜL
}

Özet

Anahtar Kelimeler

Günümüzde düzenlenen gastronomi festivalleri hem yerel bölgelerin hem de turistlerin popüler cazibe unsuru haline gelmiştir. Ziyaretçilerin ilgi odağı haline gelen ve her geçen gün sayısında artış yaşanan gastronomi festivalleri yerel yiyecek ve içeceklerin tanıtılmasında ve destinasyonu ziyaret eden kişi sayısının artmasında önemli rol oynamaktadır. Türkiye'de en fazla gastronomi festivali düzenlenen bölge Ege Bölgesi'dir. Bu doğrultuda gastronomi festivali tercihinde ziyaretçilerin memnuniyet ve bağlllık düzeylerini etkileyen faktörlerin Ege Bölgesi örneğinde belirlenmesi amaçlanmıştır. Ege Bölgesi'ndeki festivaller ziyaret edilerek festivallere katılan ziyaretçilere anket uygulanarak nicel bir çalışma gerçekleştirilmiştir. Beş gastronomi festivaline katılım sağlanmış olup 400 ziyaretçiden elde edilen verilerin analizinde Yapısal Eşitlik Modellemesi testi gerçekleştirilmiştir. Araştırmada elde edilen sonuçlara göre festival alanı faktörünün ziyaretçilerin memnuniyetini önemli ölçüde etkilediği görülmüştür. Ayrıca personel, bilgilendirme yeterliliği ve yiyecek içecek faktörünün az da olsa ziyaretçilerin memnuniyetini etkilediği; uygunluk faktörünün ise ziyaretçiler için önemli olmadığı sonucuna ulaşılmıştır.

\section{Factors Affecting Visitors' Satisfaction and Loyalty Levels in Gastronomy Festival Preference: Aegean Region Example}

Abstract

Keywords

Gastronomy festivals organized today have become a popular attraction for both local and tourists. Gastronomy festivals, which have become the centre of attention of visitors and which are increasing in number every day, play an important role in promoting local food and drink and increasing the number of people visiting the destination. Aegean Region is the region most gastronomic festival held in Turkey. In this direction, it is aimed to determine the factors affecting the satisfaction and loyalty levels of the visitors in the preference of the gastronomy festival in the Aegean Region. A quantitative study was carried out by visiting the festivals in the Aegean Region and applying a questionnaire to the visitors. Structural Equation Modeling test was carried out in the analysis of the data obtained from 400 visitors. According to the results of the study, it was seen that the festival area factor significantly affected the satisfaction of the visitors. In addition, informational adequacy and foodbeverage factors affect the satisfaction of visitors in a small although it was observed that the conformity factor was not important for the visitors.

\author{
Gastronomy Festival \\ Satisfaction \\ Loyalty
}

Aegean Region

About Article

Received: 16.07 .2019

Accepted: 26.03.2021

Doi: 10.18026/cbayarsos.592416

\footnotetext{
a Bu çalışma, Bolu Abant İzzet Baysal Üniversitesi Bilimsel Araştırma Projeleri Komisyonu tarafından 2018.16.01.1294 no'lu proje olarak desteklenen, Bolu Abant İzzet Baysal Üniversitesi Sosyal Bilimler Enstitüsü, Gastronomi ve Mutfak Sanatları Anabilim Dalında yazılan, “Gastronomi Festivallerinin Başarısını Etkileyen Faktörler: Ege Bölgesi Örneği” başlıklı yüksek lisans tezinden üretilmiştir.

b İletişim Yazarı: edemirbilek@kastamonu.edu.tr

cÖğr. Gör., Kastamonu Üniversitesi, Daday Nafi ve Ümit Çeri MYO, Otel, Lokanta ve İkram Hizmetleri Bölümü. ORCID: 0000-0002-3860-3304. d Doç. Dr., Bolu Abant İzzet Baysal Üniversitesi, Sağlık Bilimleri Fakültesi, Beslenme ve Diyetetik Bölümü. ORCID: 0000-0002-0136-4928.

e Doç. Dr., Sakarya Uygulamalı Bilimler Üniversitesi, Turizm Fakültesi, Gastronomi ve Mutfak Sanatları Bölümü. ORCID: 0000-0003-4615-1982.
} 


\section{Giriş}

Ziyaretçilerin destinasyon seçim sürecinde bölgedeki doğal çekicilikler, özel etkinlikler ve festivaller gün geçtikçe önem kazanmaktadır. Destinasyonların ziyaretçilere sunduğu tanıtım, eğlence ve huzur bulma gibi fırsatlar, gastronomi unsurlarını deneyimleme olanakları festivaller aracılığıyla kullanılabilmektedir (World Tourism Organization, 2012). Gastronomi festivalleri bölgesel turizmin gelişmesi açısından en fazla düzenlenen festival çeşidi arasındadır (Markovic, Dorcic ve Krnetic, 2015).

$\mathrm{Bu}$ çalışmanın hareket noktası Türkiye'nin sahip olduğu zengin mutfak kültürünün gastronomi festivalleri aracılığıyla tanıtımı ve pazarlanmasında festivallerin performanslarının memnuniyet ve bağllığa etkisini belirlemeye çalışmaktır. Gün geçtikçe artan gastronomi festivalleri ziyaretçilerin ilgisini çekmekte ve bölgede çekicilik unsuru haline gelmektedir. Evren olarak Ege Bölgesi örneklem olarak ise bölgede düzenlenen beş gastronomi festivali seçilmiştir. Araştırmanın gastronomi festivali ziyaretçilerinin memnuniyet ve bağlılık düzeyinin belirlenmesi açısından yazına katkılar sağlayacağ düşünülmektedir. Ayrıca araştırma kapsamında örneklem olarak belirlenen bölgede gastronomi festivallerinin tercihinde memnuniyet ve bağlılık düzeyleri tespit edilmesinin, bununla birlikte memnuniyetsizlik yaratan unsurların ortaya koyulmasının, yaşanılan aksaklıkların ortadan kaldırılması için yapılması gerekilenlerle ilgili öneriler sunulmasının gelecekte bölgede yapılacak olan gastronomi festivallerinin başarılı olabilmesi için oldukça önemli olduğu düşünülmektedir. Festival organizatörleri tarafından ziyaretçilerinin memnuniyeti için gerekli olan unsurların bilinmesi festival programlarının düzenlenmesinde ve festivallerin sürdürülebilirliğini başarı ile sağlanmasında oldukça kritik bir konudur. Gastronomi festivalleri ile ilgili gerçekleştirilen araştırma ile bu konuda faaliyet gösteren destinasyon yöneticileri, organizatör ve işletmecilere uygulamaya yönelik katkılar sağlayacağı da düşünülmektedir.

\section{Memnuniyet, Bağlılık ve Gastronomi Festivalleri}

Festivallerde ziyaretçilerin memnuniyeti oldukça önemlidir. Pazarlamada olduğu gibi turizmde de odak nokta ziyaretçilerdir. Hizmet sektörünün gün geçtikçe gelişmesi ve etkinliklerin niteliğinin ve niceliğinin artması da bunun göstergesidir.

Turizmde yer, hizmet kalitesi, fiyatlandırma, hijyen, güvenlik ve ulaşım kolaylığı gibi konular ziyaretçi memnuniyeti için önem taşımakta ve bu konularda araştırmalar yapılmaktadır (Lewis, 1987; Atkinson 1988; Knutson 1988; LeBlance, 1992). Ziyaretçi memnuniyetinin yanı sıra bağlılıkta ziyaretçilerin bir ürünü ya da hizmeti tekrar satın almasına olanak sağlamakla birlikte rekabette önemli rol oynamaktadır (Marangoz ve Biber, 2007). Günümüzde sayısında her yıl artış gösteren gastronomi festivalleri içinde durum böyledir. Gastronomiye olan ilginin artmasıyla birlikte gastronomi rotaları, gastronomi müzeleri ve gastronomi etkinlikleri ziyaretçiler tarafından tercih edilir hale gelmiştir.

Gastronomi festivali, ziyaretçilerin bilmediği yiyecek ve içecekleri deneyimlemelerine, ziyaret edilen bölgelerin kültür ve geleneği hakkında bilgi sahibi olmalarına ve yerel halkla iletişime geçerek sosyal bağ kurmalarına olanak sağlamaktadır (Mason ve Paggiaro, 2012; Wan ve Chan, 2013; Organ vd., 2015). Gastronomi festivalleri sayesinde yiyecek ve içecekler önem kazanır, bölgede ziyaretçi sayısında artış sağlanır ve toplulukların bu yolla sosyal bağ kurması sağlanabilir (Hu, 2010). Ayrıca gastronomi festivalleri, ziyaretçilerin yerinde deneyim yapmasına olanak sağlayan, üretici ve tüketiciyi buluşturan etkinliklerdir. 
Gastronomi festivalleri sayesinde ziyaretçiler festivallerde sunulan yiyecek ve içecekler hakkında bilgi sahibi olmakta ayrıca festivallerde ürünlerin yetiştirilmesi, üretilmesi ve hatta pişirilmesi gibi yöntemleri birebir gözlemlemektedirler (Mason ve Paggiaro, 2012).

Hu'ya (2010) göre, günlük yaşamın bir parçası olan yiyecekler, festivaller aracılığıyla yerel halka ve ziyaretçilere sunulur. Festivallerde yapılan programlarda ücretsiz hediyeler, çocuklar için aktiviteler, sanatsal ürünler ve sergiler, festivalde ziyaretçi memnuniyetini etkilemektedir (Cole ve Chancellor, 2009).

Lee ve Arcodia (2011) bir bölgede kullanılan yiyecek ve içeceklerin kültürel açıdan destinasyonlarda farklılaşmak için kullanıldığını belirtmişlerdir. Yöresel yiyecek ve içecekler, festivallerde ziyaretçilerin festival düzenlenen bölgelerde yeni lezzetler deneyimlemesine ve farklı gelenekleri tanımasına olanak sağlamaktadır (Kim, Eves ve Scarles, 2009). Bu deneyimin gerçekleşmesinde yiyecek ve içeceğin yanı sıra festival programında yer alan kültürel, sanatsal gibi çeşitli etkinlikler de önemli rol oynamaktadır (Cole ve Chancellor, 2009; Demirbilek, Şengül, ve Akoğlu 2018).

Geçmiş dönemlerde kırsal bölgelerde düzenlenen gastronomi festivalleri küreselleşmenin etkisiyle kentlerde düzenlenmeye başlanmış ve sayısında artış meydana gelmiştir. Gastronomi festivalleri büyükşehirlerde yoğun nüfustan, işletme sayısının fazla olmasından ve mutfak okullarının sayısındaki artıştan dolayı kolaylıkla düzenlenmektedir. Aynı zamanda büyükşehirlerde ünlü şeflerle görüşme olanağı ve mutfakta yenilikler deneme isteği (füzyon mutfak uygulamaları gibi) fazladır (Wolf, 2006). Böylece ziyaretçiler günlük yaşantısında, uzak bir yere gitmeden şehrin merkezinde bu etkinliklere katılmaktadır.

Alanyazında festival ile ilgili yapılan araştırmalarda (Crompton ve Mckay, 1997; Lee, Lee ve Wicks, 2004; Yuan vd., 2005; Thompson ve Schofield, 2009; Yolal, Çetinel ve Uysal, 2009; Duran, Hamarat ve Özkul, 2014) geniş bir şekilde katılımcı motivasyonları üzerinde durulduğu görülmektedir. Festivallerin başarısı katılımcıların duyduğu memnuniyet ve söz konusu memnuniyetin ortaya çıkardığı bağlılık ile belirlenebilir. Bu kapsamda festivallerin performansını belirlemede etkili olan yapılar ve içerikler ile ilgili gerçekleştirilen literatür taraması sonucunda festivallerin başarısını belirleyen faktörlerle ilgili farklı araştırmalara ulaşılırken (Lee vd. 2008; Özdemir ve Çulha, 2009; Anıl, 2012; Bilgili, Yağmur ve Yazarkan 2012; Özkan, Curkan ve Sarak, 2015; Sert, 2017) gastronomi festivallerinin başarısını belirleyen faktörlerle ilgili sınırlı sayıda çalışmaya ulaşılmıştır (Yuan ve Jang, 2008; Bekar, Kocatürk ve Sürücü, 2017; Kargiglioğlu ve Kabacık, 2017). Gastronomi festivallerinin son yıllarda sayısının artmış olması ve yeni oluşumlu etkinlik olması gibi nedenlerden dolayı literatürde gastronomi festivallerine yönelik çalışmaların kısıtlı olması buna neden olarak gösterilebilir. $\mathrm{Bu}$ araştırmalar sonucunda gastronomi festivallerinin başarısını belirleyen faktörler şu şekilde kavramsallaştırılabilir:

Personel: "Devlet ve diğer kamu kuruluşlarında çalışan, etkinliğe çeşitli görevleriyle katılan gerçek kişiler." şeklinde tanımlanan (TDK, 2020); müşterilerle birebir iletişimde olan personeller, müşteri memnuniyetini sağlamakla birlikte, müşterilerin beklentilerini karşılayıp sorunlara çözüm bulunabilmesi için yönetime yararlı bilgiler sunabilmektedirler (Bitner, Booms ve Mohr 1994). Bu bilgilerden hareketle gastronomi festivallerinin başarını belirleme ile personel faktörü arasındaki etkiyi belirlemeye yönelik geliştirilen hipotez şu şekildedir: 
H1: Gastronomi festivali ziyaretçilerinin gastronomi festivali tercihinde "personel" faktörüne verdikleri önem "memnuniyet" faktörü üzerinde istatistiksel olarak anlamlı etkiye sahiptir.

Yiyecek ve İçecek: İnsanların temel fizyolojik ihtiyaçlarından olan yeme ve içme, turizm sektörünün temel unsurudur (Doğdubay, Sarığlan ve Saatçi, 2011). Ziyaretçilere tatili esnasında sunulan yiyecek ve içecekler müşteri memnuniyetini olumlu ya da olumsuz etkilemektedir (Okumuş vd., 2007). Gastronomi festivallerinin temel amacı ziyaretçilerin yiyecek ve içecekleri deneyimlemesidir. Bu bilgilerden hareketle gastronomi festivallerinin başarını belirleme ile yiyecek ve içecek faktörü arasındaki etkiyi belirlemeye yönelik geliştirilen hipotez şu şekildedir:

$\mathbf{H}_{2}$ : Gastronomi festivali ziyaretçilerinin gastronomi festivali tercihinde "yiyecek ve içecek" faktörüne verdikleri önem "memnuniyet" faktörü üzerinde istatistiksel olarak anlamlı etkiye sahiptir.

Bilgilendirme Yeterliliği: Festival alanında broşürler, işaret ve levhalar ziyaretçileri yönlendirdiği için oldukça önemlidir. Bu anlamda çevresel bilgilendirmeler ziyaretçiler için önem taşımaktadır (Baker, 1986). Bu bilgilerden hareketle gastronomi festivallerinin başarısını belirleme ile bilgilendirme yeterliliği faktörü arasındaki etkiyi belirlemeye yönelik geliştirilen hipotez şu şekildedir:

$\mathbf{H}_{3}$ : Gastronomi festivali ziyaretçilerinin gastronomi festivali tercihinde "bilgilendirme yeterliliği" faktörüne verdikleri önem "memnuniyet" faktörü üzerinde istatistiksel olarak anlamlı etkiye sahiptir.

Uygunluk: Bir bölgenin istenilen özelliklere sahip olması olarak tanımlayabileceğimiz bu kelime fiziksel uygunluk olarak düşünüldügünde destinasyonların sahip olması gereken özellikler arasında sayılabilir. Yuan ve Jang, (2008) ve Baker ve Crompton (2000), tarafından yapılan çalışmalarda festival kalitesinde; festival ziyaretçileri için kolaylaştıran özelliklerden olan park etme, temizlik gibi uygunluk faktörleri olarak araştırmışlardır. Bu bilgilerden hareketle gastronomi festivallerinin başarını belirleme ile uygunluk faktörü arasındaki etkiyi belirlemeye yönelik geliştirilen hipotez şu şekildedir:

$\mathbf{H}_{4}$ : Gastronomi festivali ziyaretçilerinin gastronomi festivali tercihinde "uygunluk" faktörüne verdikleri önem "memnuniyet" faktörü üzerinde istatistiksel olarak anlamlı etkiye sahiptir.

Festival Alanı: Festivallerin düzenleneceği alanlar festivalin temel yapısı olarak görülebilir çünkü alanın büyüklüğü, programın düzenlenmesi ve sunulacak hizmetin kapsamını festival alanı belirlemektedir (Özdemir ve Çulha, 2009). Bir festivalin başarısında, festival programının içeriği ve festival faaliyetlerinin önceden planlaması önemli bir rol oynar. Bu bilgilerden hareketle gastronomi festivallerinin başarını belirleme ile festival alanı faktörü arasındaki etkiyi belirlemeye yönelik geliştirilen hipotez şu şekildedir:

H5: Gastronomi festivali ziyaretçilerinin gastronomi festivali tercihinde "festival alanı" faktörüne verdikleri önem "memnuniyet" faktörü üzerinde istatistiksel olarak anlamlı etkiye sahiptir.

Memnuniyet ve Bağlılık: Müşterinin bir mal ya da hizmeti satın almadan önceki beklentileriyle, o mal veya hizmeti satın aldıktan ve kullandıktan sonra algıladığı performans arasındaki farklılıktan doğan tutarsızlı̆̆ın fonksiyonu, memnuniyet olarak ele 
alınmaktadır (LeBlanc, 1992). Hizmet sektörü içerisinde yer alan işletmelerde tüm faaliyet ve kararların odak noktası müşteri olduğu için müşteri memnuniyeti oldukça önemlidir. Festivali organize edenlerin amacı, bu kısa zaman ve sınırlı alanda ziyaretçileri mümkün olduğunca memnun edecek hizmetleri sunmaktır. Çünkü, festivalden memnun olarak ayrılan ziyaretçiler bu memnuniyetini çevresindekilerle paylaşacak ve bir sonraki festivale katılmak içinde istekli olacaklar; böylece festivallerin sürdürülebilirliği sağlanacaktır (Kim vd., 2010). Bağlllık, bir işletmenin hizmetlerinden yararlanma derecesi, müşterinin tercih ve niyetindeki eğilim ya da marka bağlılığına yol açan psikolojik bir süreç olarak tanımlanabilir (Sudhahar vd., 2006). Ziyaretçilerin etkinliklerden memnun olması ya memnun olmaması bir sonraki festivale katılmasında rol oynamaktadır. Genel olarak, festival kalitesinin algılanan değer, tatmin ve sadakat veya davranışsal niyetleri (sadakat, başkalarına tavsiye etme) doğrudan ya da dolaylı olarak etkilediği ortaya çıkmıştır (Baker ve Crompton, 2000; Thrane, 2002; Lee, Petrick ve Crompton, 2007). Bu bilgilerden hareketle gastronomi festivallerinin başarını belirleme ile festival alanı faktörü arasındaki etkiyi belirlemeye yönelik geliştirilen hipotez şu şekildedir:

H6: Gastronomi festivali ziyaretçilerinin gastronomi festivali tercihinde "memnuniyet" faktörüne verdikleri önem "bağlllık" faktörü üzerinde istatistiksel olarak anlamlı etkiye sahiptir.

\section{Ege Bölgesi'nde Düzenlenen Gastronomi Festivalleri}

Türkiye'de düzenlenen gastronomi temalı festivallerin toplam sayısı 389'dur. Sirasiyla en çok gastronomi festivali düzenlenen bölgeler Ege Bölgesi 93, Marmara Bölgesi 92, Akdeniz Bölgesi 57, İç Anadolu Bölgesi 53, Karadeniz Bölgesi 51, Doğu Anadolu Bölgesi 28 ve Güneydoğu Anadolu Bölgesi 15'tir. Ege Bölgesi'nde düzenlenen gastronomi festivallerinin belirlenmesi için yapılan incelemeler sonunda en çok İzmir ilinde olmak üzere toplam 93 gastronomi festivali bulunduğu belirlenmiştir. Ege Bölgesi'nde düzenlenen gastronomi festivallerinin temasının büyük çoğunluğunun meyve-sebze olduğu saptanmıştır. Düzenlenen gastronomi festivallerinin büyük kısmının belediye ve kamu kurumları tarafından yapıldığı gözlenmiştir.

Ege Bölgesi coğrafi yapısından dolayı mutfak kültürü ve beslenme alışkanlıkları kıyılardan iç kesimlere gidildikçe farklılık göstermektedir. İzmir, Aydın, Muğla gibi kıyı kesimlerde bulunan şehirlerde Akdeniz tipi beslenme kültürü yaygınken Afyonkarahisar, Kütahya, Uşak ve Denizli gibi iç kesimlerde bulunan şehirlerde bu beslenme tipinden uzaklaşıldı̆̆ görülmektedir (Şengül 2015: 76). Ege Bölgesi'nde kaliteli zeytin ve zeytinyağ1, zengin ot çeşitliliği, üzüm, incir gibi meyveler halkın geçim kaynağını oluşturmakla beraber mutfağın da en büyük tamamlayıcısıdır. Bölge zengin ve lezzetli soğuk ve sıcak yemek çeşitlerine ev sahipliği yapmaktadır; ayrıca bölgenin kıyı kesimlerinde balıkçılık kültürü gelişmiştir. Bu özelliklerden dolayı zengin mutfak kültürüne sahip olması, iklim, coğrafi konum vb. Türkiye'nin en çok festival düzenlenen bölgesi olmasında etkili olduğunu göstermektedir.

\section{İlgili Çalışmalar}

Literatürde festivallerle ilgili oldukça fazla çalışma olmasına rağmen, gastronomi festivaliyle ilgili az sayıda çalışmanın olduğu görülmüştür. Özellikle Türkiye'de bu konu hakkında yapılan çalışmalar oldukça sınırlıdır. Bu çalışmayı diğerlerinden ayıran en önemli özellik sadece yiyecek ve içecek temalı olan gastronomi festivallerinin incelenmesidir. 
Chang (2006) festivallerin pazarlamada önemli olduğunu ifade ederken, Bilgili, Yağmur ve Yazarkan (2012) festivallerin bölgenin tanıtımında önemli rol oynadığını ve ziyaretçi sayısını arttırmak için önemli bir fırsat olduğunu belirtmişlerdir. Kim, Borges ve Chon, (2006) festival pazarının gittikçe çeşitlendiğini ve festival organizatörlerinin etkili pazarlama stratejileri geliştirmek için ziyaretçilerin motivasyonu hakkında bilgi sahibi olması gerektiğini belirtmiştir. Mason ve Paggiarao, (2012) gastronomi festivaline katılanların kültürel ve sosyal değişimler yaşadıklarını ve bu festivallerden psikolojik ve sanatsal açıdan olumlu etkilendiklerini belirtmiştir. Özkan, Curkan ve Sarak, (2015) gastronomi festivallerinin yerel ekonomiyi canlandırdığını ve yerel halkın gelir elde ettiğini belirtmiştir.

\section{Yöntem}

\section{Araştırma Modeli}

Çalışmanın amacı doğrultusunda ziyaretçilerin gastronomi festivali tercihlerini etkileyen faktörler ile memnuniyet ve bağlllıkla ilgili boyutta yer alan ifadelerden hangilerini öncelikli algıladıklarının tespit edilmesi ve bu boyutlar arasındaki etki düzeylerinin de ölçülmesi hedeflenmiştir. Bu kapsamda oluşturulan araştırma modeli şu şekildedir (Şekil 1):

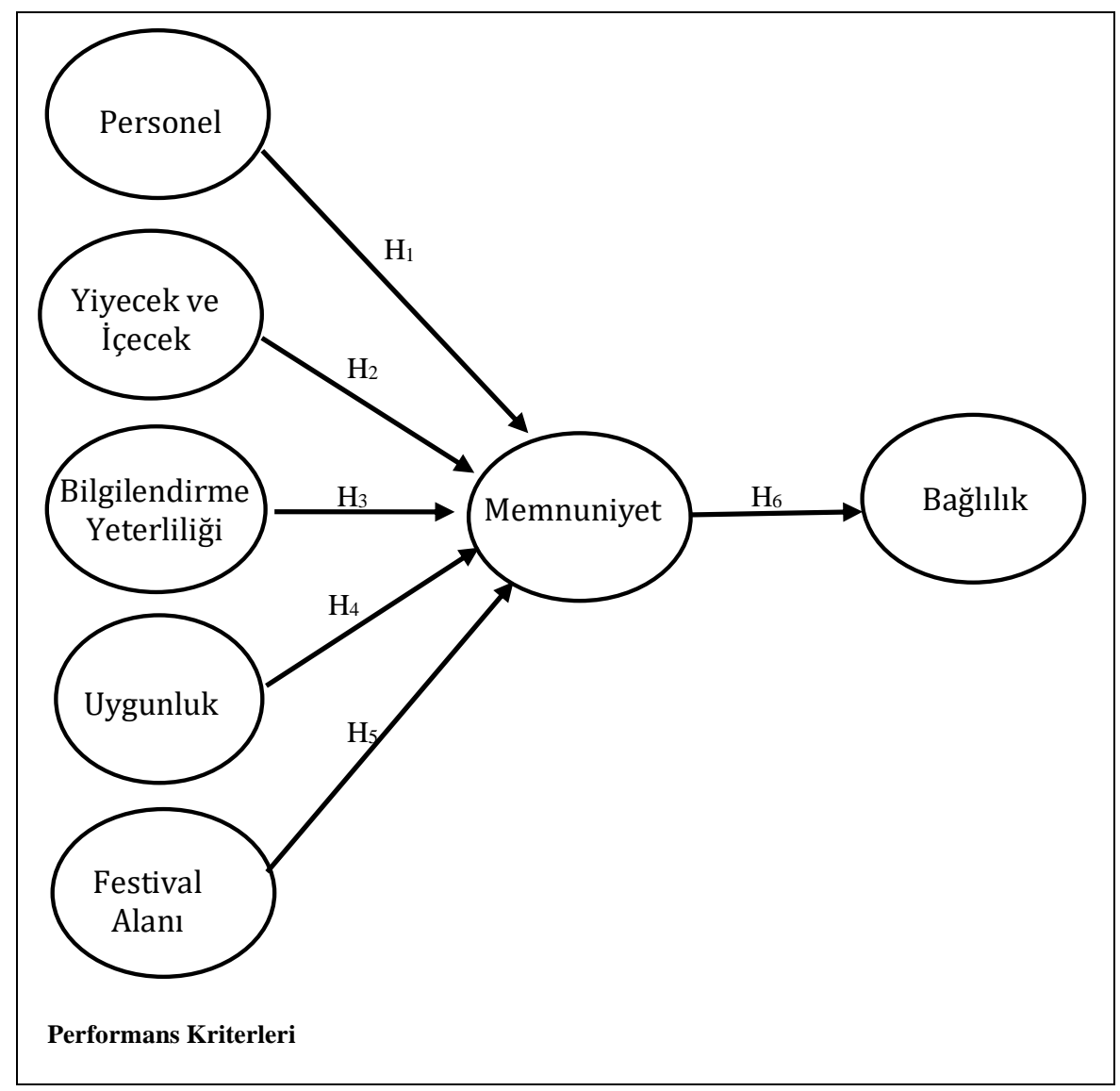

Şekil 1. Araştırma modeli

\section{Evren ve Örneklem}

Çalışma evreni olarak Ege Bölgesi'nin tercih edilme nedeni Türkiye'de düzenlenen gastronomi festivallerinin sayısının en fazla olan bölgenin Ege Bölgesi (93 adet) olması, bölgede düzenlenen gastronomi festivallerinin oldukça fazla ziyaretçi çekmesi ve bu festivallerin bölge için oldukça önemli olmasıdır. Araştırma, zaman, ekonomik faktörler ve erişilebilirlik kısıtları göz önünde bulundurularak Ege Bölgesi'ndeki bütün festivallere erişim 
sağlanamayacağı için bu bölgeden beş gastronomi festivali ile sınırlı tutulmuştur. Seçilen festivallerde zaman sınırlaması olduğu için örneğin aynı zamanda iki festivalin düzenlenmesi gibi festival seçiminde zaman büyük rol oynamıştır. Festival seçiminde dikkat edilen faktörlerden bir diğeri ise festival organizatörleridir. Festival organizatörlerinin üçe ayrıldığını ve bu üç örnekten (belediyeler, özel kurumlar, iş birlikleri) her birine yer verilmesi gerektiği düşünülmektedir. Bu nedenle Ege Bölgesi'nde belediye tarafından yapılan en büyük festivallerden biri olan İzmir/Alaçatı Ot Festivali, özel kurum tarafından düzenlenen en büyük festival olan İzmir/Çikolata ve Tatlı Festivali, belediye, kamu kurumları ve özel kurumların iş birliğiyle gerçekleştiren Fethiye/Yeşilüzümlü ve Yöresi 10. Kuzugöbeği Mantar Festivali seçilmiştir. Festivalin düzenlenme süresi faktörü ele alındığında ise Ege Bölgesi'nde en uzun süre uluslararası olarak düzenlenen ve gastronomi unsurunun ön planda olduğu festivallerden olan Manisa/Uluslararası Mesir Macunu Festivali ve Uluslararası Sultanhisar-Atça, Nysa, Çilek Tarım, Kültür ve Sanat Festivali seçilmiştir.

Çalışmanın örneklemini Ege Bölgesi'nde düzenlenen beş festivali ziyaret eden turistler oluşturmaktadır. Söz konusu festivalleri ziyaret eden turistlerin sayısı ile ilgili resmi kaynaklarca tutulmuş herhangi bir veri olmaması nedeniyle ana kütle sayısının tam olarak belirlenmesi mümkün değildir. Bu nedenle evren büyüklüğü bilinmeyen örneklem büyüklüğü hesaplama formülüne göre evreni temsil edecek örneklem sayısı 384 olarak hesaplanmıştır (Yılmaz, 2014; Yılmaz, 2016). Anketler ziyaretçiler, festivali deneyimledikten sonra festivalden ayrılışları esnasında kolayda örnekleme yöntemi ile yapılmıştır. Her festival için 83 anket doldurulmuş olup toplam 415 katılımcı tarafından yanıtlanmış; eksik ve hatalı işaretlemeler bulunan 15 anket araştırmaya dahil edilmemiş olup, 400 anket değerlendirilmiştir.

\section{Veri Toplama Araçları ve Teknikleri}

Araştırmada veri toplama aracı olarak anket tekniği kullanılmıştır. Çalışmada kullanılan anket formunun hazırlanmasında alanyazın taraması yapılmış, ancak gastronomi festivalleri ile ilgili hazır bir ölçeğe rastlanmamıştır. Bu nedenle araştırmada daha önce festivallerle ilgili kullanılmış geçerliliği ve güvenirliği sınanmış ölçekler içerisinde çalışmaya uygun olan ölçekler belirlenmiştir. Ancak bu ölçeklerde yer alan hediyelik eşya boyutu gastronomi festivallerinde hediyelik eşya ile ilgili faaliyetlerin sınırlı olmasından dolayı ölçekten çıkarılmıştır. Üç bölümden oluşan anketin; birinci bölümde, araştırmaya katılan ziyaretçilerin demografik özellikleri; ikinci bölümde araştırmaya katılan ziyaretçilerin kalış süreleri, ziyaret amaçları ve bilgi kaynakları; son bölümde ise festival performansı, memnuniyet ve bağllıkla ilgili olarak 22 önermeden oluşan bir ölçek yer almaktadır (Lee vd., 2008; Özdemir ve Çulha, 2009; Anıl, 2012). Üçüncü bölümde 5'li Likert şeklinde hazırlanan sorularda derecelendirme "Kesinlikle Katılmiyorum", “Katılmiyorum", “Ne Katılıyorum Ne Katılmıyorum", "Katılıyorum" ve "Kesinlikle Katılıyorum" şeklinde yapılmıştır.

Araştırmada kullanılan ölçek ilk olarak, Çeşme Alaçatı Ot Festivali'nde ana kütle içerisinde yer alması olası, 83 katılımcı ile kolayda örnekleme ile uygulanarak ön teste tabi tutulmuştur. Test sonucunda Cronbach Alpha $(\alpha)$ değeri 0,94 olarak bulunmuş ve ölçeğin oldukça güvenilir olduğuna karar verilmiştir. Festival tarihleri göz önünde bulundurularak 5-6 Nisan 2018'de İzmir/Alaçatı Ot Festivali, 7-8 Nisan 2018'de Muğla/Fethiye Yeşilüzümlü ve Yöresi 10. Kuzugöbeği Mantar Festivali, 20-21 Nisan 2018'de İzmir/Çikolata ve Tatlı Festivali, 24-25 
Nisan 2018'de Manisa/Uluslararası Mesir Macunu Festivali son olarak da 12-13 May1s 2018'de Aydın/Sultanhisar 49.Uluslararası Sultanhisar Atça, Nysa, Çilek, Tarım, Kültür ve Sanat Festivali'ne katılım sağlanmış belirli bir olasılık hesabına dayanmayan kolayda örnekleme yöntemi kullanılarak seçilen gastronomi festivaline katılan ziyaretçilere anket uygulanmıştır. Festivallerde araştırmacı tarafından veriler, yüz yüze anket tekniği ile festival katılımcılarından toplanmıştır

\section{Verilerin Çözümlenmesi ve Yorumlanması}

Araştırmanın amacı doğrultusunda, çalışmada elde edilen veriler doğrulayıcı faktör analizi ve yapısal eşitlik modeli ile uzman desteği alınarak yorumlanmıştır. Araştırmada veri analizi için SPSS ve AMOS paket programlarından yararlanılmıştır. Betimleyici istatistik ile ziyaretçilerin demografik özellikleri belirlenmiştir. 22 sorudan oluşan ölçeğin güvenirliliğini saptamak için Cronbach's Alpha kat sayısı hesaplanmıştır. Ziyaretçilerin ölçekteki önermelere ne düzeyde katıldığını belirlemek için yüzde dağılımı, aritmetik ortalama ve standart sapma değerleri kullanılmıştır.

\section{Bulgular ve Tartışma}

\section{Tanımlayıcı istatistik analizi}

Araştırmanın bu bölümünde ankete katılan ziyaretçilerin demografik özellikleri incelenmiştir. Araştırmaya katılan ziyaretçilerin \%65,0'i kadınlardan \%35,0'i erkeklerden oluşmaktadır. Yaş gruplarının dağılımına bakıldığında “18-24 yaş" grubu \%39,8 ile gastronomi festivalini ziyaret edenler arasında en fazla sayıda yer alırken, "65 yaş ve üstü" ziyaretçilerin bulunduğu yaş grubu \%7,8 ile en az sayıda katılım gösteren yaş grubu olduğu tespit edilmiştir. Araştırmaya katılanların eğitim düzeyleri incelendiğinde "lise" eğitimi alanların \%30,5 ile "lisans" eğitimi alanların \%29,7 ile en kalabalık ziyaretçi grubunu oluşturduğu, "lisansüstü" eğitimi alanların ise \%4,8 ile en az ziyaretçi grubunu oluşturduğu görülmektedir. Araştırmaya katılanların medeni durumları incelendiğinde \%64,5'inin "bekâr" ve \%35,5'inin "evli" oldukları görülmektedir. Araştırmaya katılan ziyaretçilerin meslek grupları incelendiğinde "öğrenci" olanların \%41,3 ile ilk sırada, "serbest meslek" grubunda yer alanlarında \%19,3 ile ikinci sırada yer aldığı tespit edilmiştir. Araştırmaya katılanların gelir durumlarına bakıldığında ise en fazla gelir durumuna sahip ziyaretçilerin $\% 53,3$ ile "0-1500 TL" arasinda en az gelir durumu grubunun ise \%1,5 ile "4501-5000 TL" aylık gelir olduğu görülmüştür.

Tablo 1. Ziyaretçilerin Demografik Özellikleri

\begin{tabular}{|cccccc}
\hline Cinsiyet & Sayı & Yüzde (\%) & Medeni Durum & Sayı & Yüzde (\%) \\
Kadın & 260 & 65,0 & Bekâr & 257 & 64,3 \\
Erkek & 140 & 35,0 & Evli & 143 & 35,8 \\
Toplam & $\mathbf{4 0 0}$ & $\mathbf{1 0 0}$ & Toplam & $\mathbf{4 0 0}$ & $\mathbf{1 0 0}$ \\
\hline Eğitim Düzeyi & Sayı & Yüzde (\%) & Yaş & Sayı & Yüzde (\%) \\
\hline Illkokul & 40 & 10,0 & $18-24$ yaş & 159 & 39,8 \\
Ortaokul & 28 & 7,0 & 25-34 yaş & 91 & 22,8 \\
Lise & 122 & 30,5 & $35-44$ yaş & 71 & 17,8 \\
Önlisans & 72 & 18,0 & $55-64$ yaş & 45 & 11,3 \\
Lisans & 119 & $\mathbf{2 9 , 8}$ & 65 ve üstü & 31 & 7,8 \\
Lisansüstü & 19 & 4,8 & Toplam & $\mathbf{4 0 0}$ & $\mathbf{1 0 0}$ \\
Toplam & $\mathbf{4 0 0}$ & $\mathbf{1 0 0}$ & & & \\
Meslek & Sayı & Yüzde (\%) & Aylık Gelir & Sayı & Yüzde (\%)
\end{tabular}




\begin{tabular}{cccccc} 
Memur & 28 & 7,0 & $0-1500 \mathrm{TL}$ & 213 & 53,3 \\
İşçi & 50 & 12.5 & $1501-2500 \mathrm{TL}$ & 108 & 27,0 \\
Serbest Meslek & 77 & 19,3 & $2501-3500 \mathrm{TL}$ & 45 & 11,3 \\
Emekli & 39 & 9,8 & $3501-4500 \mathrm{TL}$ & 12 & 3,0 \\
Öğrenci & 165 & 41,3 & $4501-5000 \mathrm{TL}$ & 6 & 1,5 \\
İşsiz & 41 & 10,3 & 5001 ve Üstü & 16 & 4,0 \\
Toplam & $\mathbf{4 0 0}$ & $\mathbf{1 0 0}$ & Toplam & $\mathbf{4 0 0}$ & $\mathbf{1 0 0}$ \\
\hline
\end{tabular}

Araştırmaya katılan ziyaretçilerin; bölgeye geliş nedeni olarak \%81,2'sinin "festival", çok az sayıda ziyaretçinin ise \%6,3 "iş" için geldiği görülmektedir. Ziyaretçilerin konaklama süreleri değerlendirildiğinde \%59,0 ile ilk sırada "günübirlik" cevabını verdiği görülürken en az sayıda ise \%6,5 ile "3-5 gece" cevabını görülmektedir. Ziyaretçilerin konakladıkları yer incelendiğinde ilk sırada \%56,5 ile konaklama yapmadıklarını ve en az sayıda cevap olarak \%5,5 ile "otel" de konakladıkları tespit edilmiştir. Ziyaretçilerin bilgi kaynağı incelendiğinde en fazla \%51,0 ile "arkadaş/akraba tavsiyesi", \%44,0 ile "internet/sosyal medya" ve en az bilgi kaynağ1 olarak da \%2,0 ile “TV-gazete-dergi” olduğu görülmüştür.

Tablo 2. Araştırmaya Katılan Ziyaretçilerin Kalış Süreleri, Ziyaret Amaçları ve Bilgi Kaynakları

\begin{tabular}{cccccc}
\hline Bölgeye Geliş Nedeni & Sayı & Yüzde (\%) & Bilgi Kaynakları & Sayı & Yüzde (\%) \\
Festival & 325 & 81.3 & Arkadaş/Akraba Tavsiyesi & 204 & 51,0 \\
Tatil & 50 & 12,5 & İnternet/ Sosyal Medya & 176 & 44,0 \\
İş & 25 & 6,3 & TV/Dergi/Gazete & 8 & 2,0 \\
Toplam & $\mathbf{4 0 0}$ & $\mathbf{1 0 0}$ & Toplam & $\mathbf{4 0 0}$ & $\mathbf{1 0 0}$ \\
Konaklama Süresi & Sayı & Yüzde (\%) & Konaklanan Yer & Sayı & Yüzde (\%) \\
Günübirlik & 236 & 59.0 & Otel & 22 & 5,5 \\
1-2 Gece & 95 & 23,8 & Apart Otel & 38 & 9,5 \\
3-5 Gece & 26 & 6,5 & Arkadaş & 55 & 13,8 \\
5 Geceden Fazla & 43 & 10,8 & Akraba Yanında & 59 & 14,8 \\
Toplam & $\mathbf{4 0 0}$ & $\mathbf{1 0 0}$ & Yok & 226 & 56,5 \\
& & & Toplam & $\mathbf{4 0 0}$ & $\mathbf{1 0 0}$ \\
\hline
\end{tabular}

Ziyaretçilerin gastronomi festivali tercihindeki memnuniyet unsurları hakkındaki görüşleri

Katılımcıların gastronomi festivali memnuniyetinde etkili olan faktörlere göre sorular oluşturulmuş ve verilen yanitlar aritmetik ortalama ve standart sapma değerlerine göre analiz edilmiştir (Tablo 3). Boyutların ortalamalarına göre gastronomi festivali tercihi boyutları içerisinde en fazla katılım gösterilen boyutun personel olduğu tespit edilmiştir (a.o. $=3,82$, s.s. $=0,931$ ). Bu boyutu ikinci sirada 3,23 ortalama ile festival alanının (s.s. $=1,019)$, üçüncü sırada 3,19 ortalama ile yiyecek ve içecek (s.s.=1,003), dördüncü sırada ise 3,14 ortalama ile bilgilendirme yeterliliği (s.s.=1,001), izlemektedir. Son olarak uygunluk (s.s.=1,007) boyutunun da 2,06 ortalama değere sahip olduğu tespit edilmiştir. Bu değerler gastronomi festivali tercihleri boyutları içerisinde personel, festival alanı ve yiyecek içeceğin daha yüksek performans gösterdiği ortaya koymakla birlikte uygunluğun daha az performans gösterdiğini ortaya çıarmaktadır. Uygunluk faktörü ile ilgili sorulara verilen cevapların düşük aritmetik ortalamaya sahip olması dikkat çekicidir. 
Tablo 3. İfadelerin ve Boyutların Aritmetik Ortalama ve Standart Sapmaları

\begin{tabular}{|c|c|c|c|}
\hline No & Ífadeler & $\begin{array}{l}\text { Aritmetik } \\
\text { Ortalama }\end{array}$ & $\begin{array}{l}\text { Standart } \\
\text { Sapma }\end{array}$ \\
\hline & Personel & 3,82 & 0,931 \\
\hline 1 & Festivalde görev alanlar (personel, tezgahtar vb.) çok nazikti. & 3,88 & 1,021 \\
\hline 2 & $\begin{array}{l}\text { Festivalde görev alanlar (personel, tezgahtar vb.) festival hakkında } \\
\text { yeterli bilgiye sahipti. }\end{array}$ & 3,79 & 0,992 \\
\hline 3 & $\begin{array}{l}\text { Festivalde görev alanlar (personel, tezgahtar vb.) isteğimize hızlı bir } \\
\text { sekilde cevap vermekteydi. }\end{array}$ & 3,81 & 1,038 \\
\hline \multirow[t]{2}{*}{4} & $\begin{array}{l}\text { Festivalde görev alanlar (personel, tezgahtar vb.) bize yardımcı olmaya } \\
\text { hazırdı. }\end{array}$ & 3,81 & 1,016 \\
\hline & Yiyecek ve İçecek & 3,19 & 1,003 \\
\hline 5 & Festival sırasında satılan yiyecekler çok kaliteliydi. & 3,53 & 1,135 \\
\hline 6 & Geleneksel yemekler vardı. & 3,32 & 1,363 \\
\hline 7 & Yeterli çeşitlilikte yiyecek vardı. & 3,35 & 1,365 \\
\hline \multirow[t]{2}{*}{8} & Gida fiyatları uygundu. & 2,60 & 1,204 \\
\hline & Bilgilendirme Yeterliliği & 3,14 & 1,001 \\
\hline 9 & Broşürler yeterli bilgi sağlamaktaydı. & 3,11 & 1,132 \\
\hline 10 & Tabelalar yeterli bilgi sağlamaktaydı. & 3,19 & 1,087 \\
\hline \multirow[t]{2}{*}{11} & Ziyaretçiler için festival alanını gösteren işaretler yeterli bilgi & 3,15 & 1,165 \\
\hline & Uygunluk & 2,66 & 1,007 \\
\hline 12 & Tuvaletler kullanışlıydı. & 2,59 & 1,190 \\
\hline 13 & Dinlenme alanları yeterliydi. & 2,74 & 1,311 \\
\hline \multirow[t]{2}{*}{14} & Park yeri yeterliydi. & 2,68 & 1,260 \\
\hline & Festival Alanı & 3,23 & 1,009 \\
\hline 15 & Festival alanının büyüklüğü yeterliydi. & 3,10 & 1,286 \\
\hline \multirow[t]{2}{*}{16} & Festivalde çeşitli etkinlikler vardı. & 3,37 & 1,164 \\
\hline & Memnuniyet & 3,65 & 1,000 \\
\hline 17 & Bu festivalde kendimi çok iyi hissettim. & 3,59 & 1,015 \\
\hline 18 & Bu festivali ziyaret etme kararımdan memnunum. & 3,68 & 1,077 \\
\hline \multirow[t]{2}{*}{19} & Genel olarak bu festivalden memnunum. & 3,70 & 1,097 \\
\hline & Bağhllık & 3,64 & 1,010 \\
\hline 20 & Bu festivali arkadaşlarıma ve komşularıma tavsiye ederim. & 3,63 & 1,154 \\
\hline 21 & Bu festival hakkında diğer insanlara olumlu şeyler söyleyeceğim. & 3,65 & 1,118 \\
\hline 22 & Bu festivali bir dahaki sefere tekrar ziyaret etmek isterim. & 3,66 & 1,170 \\
\hline
\end{tabular}

\section{Ölçüm modeline ilişkin test sonuçları (doğrulayıcı faktör analizi)}

Çalışmada kullanılan ankette yer alan ölçeklerin yapı geçerliliği araştırılmıştır. DFA modeli ile verilenin başlangıçtaki teorik modeli doğrulayıp doğrulamadığı araştırılmaktadır. Bu durumu sağlayan bir faktör yapısının varlığı ve söz konusu yapının istatistiksel olarak anlamlılı̆g 1 test edilmektedir. Bunun sonrasında modele uygun olan ek örneklem verisiyle, hipotezlenen modelin geçerliliği doğrulanır (Schumacker ve Lomax, 2004). Uyum iyiliği ölçütü, bir modelin bütün olarak kabul edilebilmesi için verilerin birbiriyle tutarlı olup olmadığını belirler. Bir teorik modelin veri ile uyumunun analizinde birçok yöntem kullanılmaktadır. Bu model ile veri arasındaki uyumu analiz ederken, uyum iyiliği 
testlerinden tamamı ya da birkaçı kullanılabilmektedir (Schumacker, 2006). Ölçüm modelinin uyumunu göstermek amacıyla $x^{2}, x^{2} / d f$, RMSEA, GFI, CFI ve NFI gibi uyum iyiliği değerleri incelenmiştir. Tablo 4 incelendiğinde DFA modelinin; $\mathrm{x}^{2} / \mathrm{df}$, RMSEA, CFI, GFI ve NFI kriterlerine göre kabul edilebilir düzeyde uyumlu olduğu görülmektedir. Bununla birlikte Ki-kare sonucu modelin uyumlu olmadığını göstermektedir. Ki-kare bir anlamlılık testidir. Örneklem büyüklügüne duyarlılık göstermekle birlikte hemen hemen her modelde de ret edilmektedir (Bentler ve Bonett, 1980). Araştırmada elde edilen uyum iyiliği değerlerinin büyük kısmının uyumlu olduğu sonucunu vermesi nedeniyle genel olarak model kabul edilmektedir.

Tablo 4. Ölçeğe İlişkin Uyum Değerleri

\begin{tabular}{ccc}
\hline Uyum Ölçüsü & Ölçek Değeri & Sonuç \\
Ki Kare $\left(x^{2}\right)$ & $564,782 \mathrm{p}=0,000$ & Model uyumlu değil \\
$x^{2} / d f$ & $564,782 / 188=3,004$ & Model kabul edilebilir düzeyde uyumlu \\
RMSEA &, 071 & Model orta derece uyumlu \\
GFI & 0,892 & Model kabul edilebilir düzeyde uyumlu \\
CFI & 0,952 & Model kabul edilebilir düzeyde uyumlu \\
NFI & 0,931 & Model kabul edilebilir düzeyde uyumlu \\
\hline
\end{tabular}

Çalışmada ilgili ölçeklerin yapı geçerliliği için ML (en çok benzerlik) algoritmasına dayanan doğrulayıcı faktör analizi yapılmıştır. Yapılan analiz sonucunda soruların tamamına ilişkin Cronbach's Alfa değerleri ve standart yük değerleri kabul edilebilir değerlerin üstünde $(>0,50)$ yer aldığı görülmüştür (Cortina, 1993). Kurulan modele ilişkin elde edilen uyum değerleri ve anlamları Tablo 5 'te verilmiştir.

Tablo 5. DFA Analizi Sonucu Elde Edilen Standart Yük ve Cronbach's Alfa Değerleri

\begin{tabular}{|c|c|c|c|}
\hline Boyut & Önerme & Standart Yük Değeri & Cronbach's Alfa Katsayısi \\
\hline \multirow{4}{*}{ PERSONEL } & 1 & ,869 & \multirow{4}{*}{ - } \\
\hline & 2 & ,889 & \\
\hline & 3 & ,910 & \\
\hline & 4 & ,877 & \\
\hline \multirow{4}{*}{ YİYECEK VE IÇECEK } & 5 & ,721 & \multirow{4}{*}{829} \\
\hline & 6 & ,843 & \\
\hline & 7 & 867 & \\
\hline & 8 &, 566 & \\
\hline \multirow{3}{*}{ BİLGÍLENDİRME } & 9 & 836 & \multirow{3}{*}{,885 } \\
\hline & 10 & ,923 & \\
\hline & 11 & ,804 & \\
\hline \multirow{3}{*}{ UYGUNLUK } & 12 & ,727 & \multirow{3}{*}{, 824} \\
\hline & 13 &, 846 & \\
\hline & 14 & ,781 & \\
\hline \multirow{2}{*}{ FESTIVAL ALANI } & 15 & ,812 & \multirow{2}{*}{,748 } \\
\hline & 16 & ,739 & \\
\hline \multirow{3}{*}{ MEMNUNIYYT } & 17 &, 869 & \multirow{3}{*}{, 944} \\
\hline & 18 &, 948 & \\
\hline & 19 & 949 & \\
\hline \multirow{3}{*}{ BAĞLILIK } & 20 & ,955 & \multirow{3}{*}{,962 } \\
\hline & 21 & ,959 & \\
\hline & 22 & 920 & \\
\hline
\end{tabular}


Yapısal eşitlik modeline ilişkin test sonuçları (YEM)

Kurulan modele ilişkin yol katsayıları ve diğer açıklayıcı bilgiler Tablo 6'da görülmektedir. Test edilen model sonuçlarına geçilmeden önce yapılan incelemede, negatif hata varyansın olmadığ 1 ve hata terimlerinin 1'den yüksek yüklemeler almadığı görülmüştür. Yapısal eşitlik analizi ile ölçüm modeli sonucu elde edilmiştir. Bunun ardından iyi uyuma sahip olan değişkenler ile model oluşturulup bu model test edilmiştir. Son olarak model sonuçlarının değerlendirilmesine geçilmiştir. Tablo 6 'da göre iki değişken (gözlenen ve gözlenemeyen) için olasılık (p) değerlerinin biri hariç diğerleri 0,05'den küçük olduğu için regresyon katsayıları anlamlıdır. Analiz sonucu üretilen uyum değerlerinin kabul edilen uyum indekslerinin üzerinde veya altında olması istenir. Bu çalışmada da alanyazında en fazla kullanılan uyum indeksleri kullanılmıştır. YEM uyum iyiliği değerleri incelendiğinde bu değerlerin daha önce gerçekleştirilen DFA uyum değerlerine çok yakın sonuçlar (Ki Kare $\left(x^{2}\right): 563,445 ; x^{2} / d f:$ 2,935; RMSEA: ,070; CFI: 0,953; NFI:0,931) çıktığ1 görülmektedir. Böylece YEM'in genel olarak kabul edilebilir uyuma sahip olduğu söylenilebilir.

Tablo 6 incelendiğinde, "uygunluk" ile "memnuniyet" arasında kurulan bağ dışındaki tüm yollar anlamlıdır. Belirtilen varyanslar incelendiğinde, "memnuniyet"e ilişkin varyansın, \%56'sının "personel", "yiyecek ve içecek", "bilgilendirme yeterliliği", "festival alanı", faktörlerindeki değişimlerden kaynaklandığ 1 ; "bağl1lık"a ilişkin varyansın ise, \%76'sının "memnuniyet" faktöründeki değişimler tarafından açıklandığı görülmektedir.

Tablo 6. Yapısal Modele İlişkin İstatistik Değerler

\begin{tabular}{|c|c|c|c|c|}
\hline Yol & Standart Yol Katsayısı & Standart Hata & Anlamlilik & $R^{2}$ \\
\hline PRS $\rightarrow$ MMY & ,311 & ,064 &, 000 & \multirow{5}{*}{0,56} \\
\hline Yİ $\rightarrow M M Y$ & 204 & 107 & 021 & \\
\hline $\mathrm{BLY} \rightarrow \mathrm{MMY}$ & 174 & 062 & ,005 & \\
\hline UYG $\rightarrow$ MMY &,- 111 & 102 & 280 & \\
\hline $\mathrm{FA} \rightarrow \mathrm{MMY}$ &, 581 & 147 & 000 & \\
\hline $\mathrm{MMT} \rightarrow \mathrm{BAG}$ & ,979 & ,033 & ,000 & 0,76 \\
\hline Uyum Değerleri & \multicolumn{4}{|c|}{$x^{2}=563,445 ; p=0,000 ; x^{2} / d f=2,935 ; C F I=0,953 ; N F I=0,931 ;$ RMSEA $=, 070$} \\
\hline
\end{tabular}

Hipotez testleri

"Ziyaretçiler açısından gastronomi festivali ziyaretçilerinin tercihlerini etkileyen faktörler, memnuniyet ve bağgllık düzeylerinin" araştırılması amacı ile geliştirilen yapısal model testi sonucunda elde edilen boyutlar arasındaki standart tahmin değerleri ve araştırma hipotezlerini kapsayan yapı Şekil 2' de gösterilmektedir. 


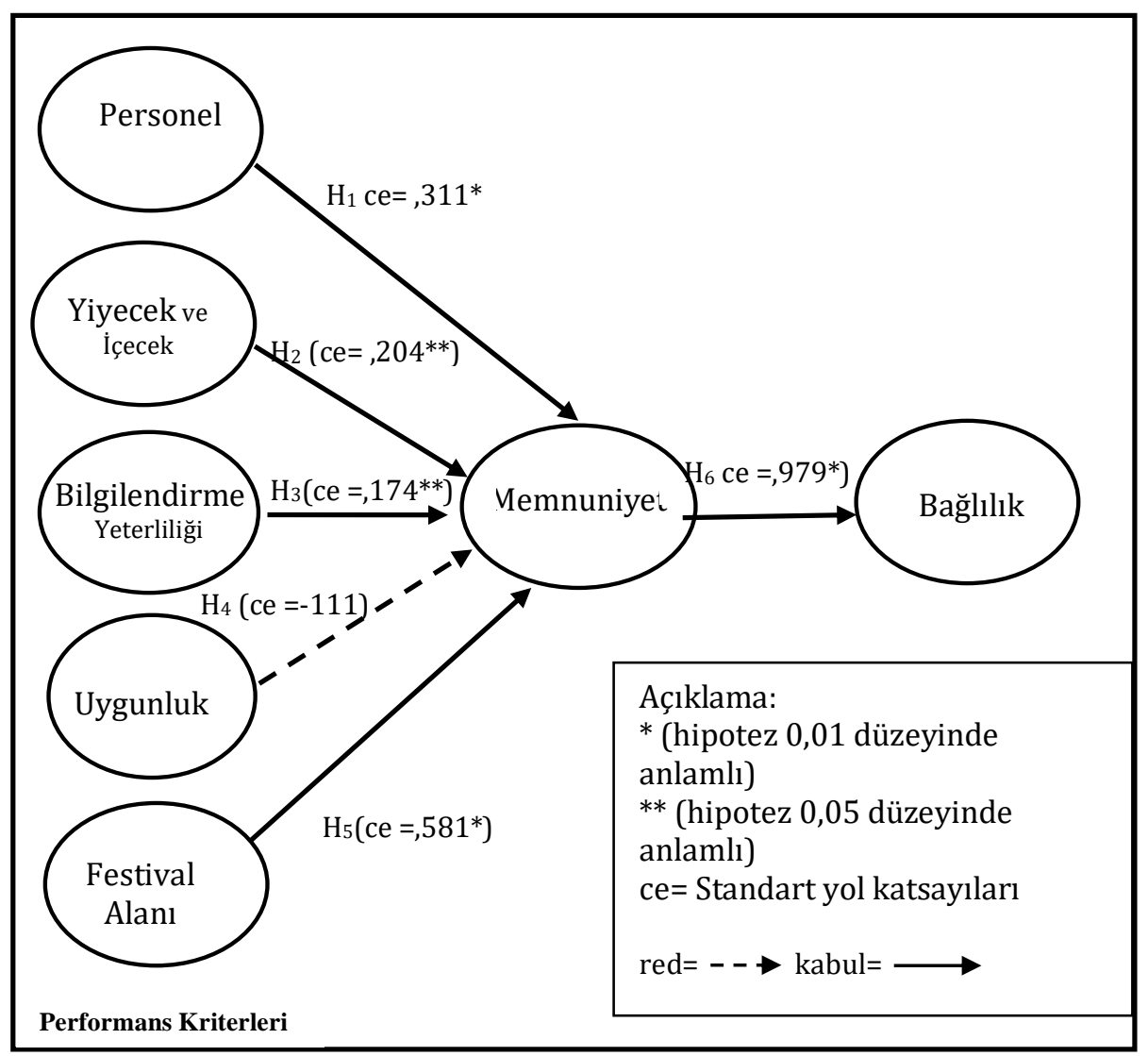

Şekil 2. Standart tahmin değerleri ve hipotez sonuçları

Çalışmada elde edilen hipotez testleri sonucunda gastronomi festivallerini ziyaret eden ziyaretçilerin memnuniyetiyle ilgili ortaya koyulan hipotezlerden "personel", "yiyecek ve içecek", "bilgilendirme yeterliliği", "festival alanı" ve "memnuniyet" faktörlerinin kabul edildiği, "uygunluk" faktörünün reddedildiği görülmektedir. Hipotez testi sonuçlarına ilişkin özet Tablo 7'de gösterilmiştir. Bu kapsamda çalışmanın başında önerilen 6 hipotezin 5'i desteklenirken 1 hipotez desteklenmemiştir.

Tablo 7. Hipotez testi sonuçları

\begin{tabular}{ccc}
\hline Hipotez & Kisaltmalar & Sonuç \\
$\mathrm{H}_{1}$ & PRS $\rightarrow$ MMY & Desteklendi $(\mathrm{ce}=0,311)$ \\
$\mathrm{H}_{2}$ & Yİ $\rightarrow$ MMY & Desteklendi $(\mathrm{ce}=0,204)$ \\
$\mathrm{H}_{3}$ & BLY $\rightarrow$ MMY & Desteklendi $(\mathrm{ce}=0,174)$ \\
$\mathrm{H}_{4}$ & $\mathrm{UYG} \rightarrow \mathrm{MMY}$ & Desteklenmedi $(\mathrm{ce}=-0,111)$ \\
$\mathrm{H}_{5}$ & FA $\rightarrow$ MMY & Desteklendi $(\mathrm{ce}=0,581)$ \\
$\mathrm{H}_{6}$ & MMT $\rightarrow$ BAG & Desteklendi $(\mathrm{ce}=0,979)$ \\
\hline
\end{tabular}

\section{Sonuç ve Öneriler}

Araştırmada gastronomi festivali ziyaretçilerinin tercihlerini etkileyen faktörler, memnuniyet ve bağlılık düzeyleri tespit edilmeye çalışılmıştır. Bu bağlamda, gastronomi festivaline katılan ziyaretçilere anket uygulanmıştır. Araştırmada elde edilen bulgular doğrultusunda gastronomi festivaline gelen ziyaretçi profili hakkında bazı tanımlayıcı sonuçlara ulaşılmıştır. 
Festivallere kadın, bekar, genç ve öğrencilerin katılımının yüksek olduğu görülmektedir. Festivallerde yapılan etkinliklerin gençler ve öğrenciler tarafından daha çok ilgi görmesi festival programlarının eğlenceli etkinlikler içermesiyle bağlantılı olduğu söylenebilir. Ayrıca araştırmaya katılanların aylık gelirinin düşük olduğu görülmektedir. Ankete katılanlar arasında öğrencilerin büyük çoğunlukta olması gelir durumunun düşük olmasının nedeni olarak açıklanabilir. Ziyaretçilerin büyük çoğunluğunun festival için bölgeye geldiği görülmüştür. Bu sonuç festivallerin ziyaretçilerin gideceği yeri seçmesinde önemli bir çekiciliğinin olduğunu göstermektedir. Konaklama açısından ziyaretçilerin büyük kısmının günübirlik geldiği görülmüştür. Bu sonuç festivallere yakın il ve ilçelerden katılım sağlandığı şeklinde yorumlanabilir. Festivale katılan ziyaretçilerin festival hakkında aldıkları bilgi kaynaklarının arkadaş/akraba tavsiyesi ve internet-sosyal medya aracılığıyla olduğu görülmüştür. Bu durum festival organizatörlerinin interneti ve sosyal medyayı etkin kullandıkları veya festival takipçilerinin sosyal medyadan etkileşime açı olduklarını göstermektedir. Gastronomi festivali düzenleyen organizatörlerin ziyaretçilerin profilini bilmesi bu doğrultuda planlama yapması ve ziyaretçilerin memnuniyetine önem vermesi ziyaretçi sayısında artış yaşanabileceğini göstermektedir. Festivalden memnun olan ziyaretçiler festivali tekrar tercih etme ve başkalarına önerme konusunda istekli oldukları çalışmaya paralel olarak birçok araştırma sonucunda da yer almaktadır (Lee vd., 2008; Özdemir ve Çulha, 2009; Anıl, 2012). Ayrıca ziyaretçilerin büyük kısmının festivalde konaklama yapmadıkları görülmektedir. Organizatörlerin ziyaretçilerin konaklama yapması için programlarını geliştirilmesi gerektiği düşünülmektedir.

Yapısal eşitlik modeline ilişkin sonuçlara bakıldığında, festivalde yiyeceklerin kaliteli, yeterli çeşitlilikte ve geleneksel olması gibi ifadelerden oluşan "yiyecek-içecek" faktörü ile ziyaretçilerin memnuniyeti arasında pozitif yönlü anlamlı ilişki ortaya çıkmıştır. Gıda fiyatlarının uygun olduğunu belirten ifade ortalamasının ise düşük çıkması dikkat çekicidir. Araştırma kapsamında gastronomi festivali tercihindeki memnuniyet unsurları içerisinde yer alan "personel", "bilgilendirme yeterliliği" ve "festival alanı" faktörleri ile ziyaretçilerin memnuniyeti arasında pozitif yönlü anlamlı bir ilişki ortaya çıkmıştır. Festival alanının büyük olması ve yapılan etkinliklerin çeşitli olması yemek yarışmaları, tadım atölyeleri, workshoplar gibi aktiviteler ziyaretçilerin dikkatini çekmekte olup etkinliklere katılımı arttırdığı görülmektedir. Festival programının zengin olması yeterli çeşitte etkinlikler yapılması ve ziyaretçiler tarafından katılım sağlanması festival memnuniyetini olumlu etkilediği sonucuna ulaşılmıştır. Tuvalet, dinlenme alanı ve park yeri gibi ifadelerin yer aldığı "uygunluk" faktörünün ise ziyaretçiler için önemli olmadığ 1 sonucuna ulaşılmıştır. Bunda ziyaretçilerinin büyük kısmının öğrenci, genç ve gelir durumunun düşük olmasında etkili olduğu düşünülmektedir. Öğrencilerin kendi araçlarına sahip olmaması ve festivale toplu taşıma aracıyla ulaşımın sağlanması bunun içinde park yerine gereksinim duyulmaması, genç yaşta olmalarından dolayı dinlenme alanlarına gereksinim duyulmaması bunun yerine daha çok aktivitelere önem vermesinin etkili olduğu düşünülmektedir. Araştırma kapsamında "memnuniyet" faktörü ile bağlılık arasında pozitif yönlü anlamlı bir ilişki ortaya çıkmıştır. Araştırmada elde edilen sonuçlara göre festival alanı faktörünün ziyaretçi memnuniyetini önemli ölçüde etkilediği görülürken personel, bilgilendirme yeterliliği ve yiyecek-içecek faktörlerinin az da olsa ziyaretçilerin memnuniyeti ve bağlılığını etkilediği, uygunluk faktörünün ise ziyaretçiler için önemli olmadığı görülmüştür.

Özdemir ve Çulha (2009) "Festival Ziyaretçilerinin Memnuniyeti ve Bağlılığı", çalışmasında festivallerde ziyaretçilerin memnuniyeti ve bağlılığını; festival alanı, personel, yiyecek, 
uygunluk, hediyelik eşya ve bilgilendirme faktörleriyle incelemiş ve benzer olarak "festival alanının" ziyaretçi memnuniyetini etkileyen en önemli etken olduğunu bildirmişlerdir. Çalışmada festival alanı faktörleri içerisinde; festival alanının yeterli imkana sahip ve büyük olması, temizliği, programın iyi organize edilmesi, dinlenme alanının yeterli olması, alanın atmosferinin iyi olması ve çeşitli etkinliğin yapılmasının ziyaretçilerin en çok önem verdiği husus olarak görülmektedir. Yapılan çalışmanın sonuçlarına paralel olarak festival alanının ziyaretçilerin memnuniyeti için önemli olduğu görülmüştür. Aynı zamanda çalışmada yiyecek, hediyelik eşya ve personel davranışlarının ziyaretçi memnuniyeti ve bağlılığını önemsiz düzeyde etkilediğini belirtmişlerdir. Yapılan araştırmanın örnekleminin Efes Deve Güreşi Festivali'nin olmasında etkili olduğu düşünülmektedir çünkü deve güreşi festivalinde festival alanının büyüklüğü yiyecek ve içecekten, hediyelik eşyadan daha önemlidir. Araştırmanın bu sonucu göz önüne alındığında ise gastronomi festivalinde "yiyecek- içecek" faktörünün önemli olması kaçınılmaz bir sonuçtur.

Anıl (2012) “Festival Ziyaretçilerinin Memnuniyet ve Bağl1lı̆̆ı: Küçük, Yerel ve Belediye Tarafından Organize Edilen Festivaller Örneği", adlı çalışmasında festivallerde ziyaretçilerin memnuniyet ve bağlılığını incelediği çalışmada örneklem olarak Vize Tarih ve Kültür Festivali'ni araştırmıştır. Festival alanı, personel, yiyecek, uygunluk, hediyelik eşya, bilgilendirme yeterliliği faktörlerini incelemiştir. Yiyecek faktörünün, ziyaretçilerin memnuniyeti için en önemli faktör olduğu ve sadakati önemli ölçüde etkilediği sonucuna ulaşılırken; hediyelik eşya, personel ve bilgilendirme yeterliliği faktörlerinin ziyaretçilerin memnuniyetini ve bağlılığını önemli ölçüde etkilemediği sonucuna ulaşılmıştır. Bu boyutla ilgili olası açılamalar festival ile ilişkilendirilebilir. Festivalin türünün, festivalin düzenlendiği bölgenin özelliği gibi faktörlerin bunda etkili olduğu düşünülmektedir. Yerel ve küçük çapta festival düzenlenmesi, festival alanının küçük olmasıyla beraber personellerin önemli olmadığı, bilgilere ulaşımın daha kolay olması bunda etkendir.

Lee vd. (2008) “Festivallerde Ziyaretçilerin Duyguları, Memnuniyeti ve Bağlılı̆̆ı” yaptığı çalışmada aynı sonuçlar ortaya çıkmıştır. Anıl (2012) çalışmasında Özdemir ve Çulha (2009)'nın yaptığı çalışmanın aksine festival alanı faktörü yapılan araştırmaya benzer şekilde sadece iki unsurdan oluşmaktadır: Bunlar, festivaldeki yeterli etkinlikler ve festival alanının büyüklüğü'dür. Çalışmanın sonuçları çalışmamıza paralel olarak festival alanı ve yiyecek faktörüne ziyaretçilerin memnuniyetini olumlu etkilediğini göstermiştir.

Bu çalışma, uygulamanın sınırları nedeniyle bir bölgede ve beş festivalde yürütülmüştür. Konunun daha ayrıntılı incelenmesi için ileride yapılacak araştırmanın kapsamı büyütülerek birkaç farklı bölgede ya da bir bölgede daha fazla festival üzerinde gerçekleştirilebilir.

\section{Kaynakça}

Anıl, N. K. (2012). Festival Visitors' Satisfaction and Loyalty: An Example of Small, Local, and Municipality Organized Festival, Tourism: An International Interdisciplinary Journal, 60 (3): 255271.

Atkinson, A. (1988). Answering the Etemal Question: What Does the Customer Satisfaction, The Cornell Hotel and Resteurolll Adninistraiion Quarterly, 29 (2): 45-5 1. 
Baker J. (1986). The role of the environment in marketing services: the consumer perspective. In: Czepiel JA, Congram CA, Shanahan J, editors. The Services Challenge: Integrating for Competitive Advantage. Chicago: American Marketing Association; 79-84.

Baker, D. A. ve Crompton, J. L. (2000). Quality, Satisfaction And Behavioral Intentions, Annals of Tourism Research, 27 (3) :785-804.

Bekar, A. Kocatürk, E. ve Sürücü, Ç. (2017). Gastronomi Festivallerinin Algılanan Destinasyon İmajina ve Tekrar Ziyaret Etme Niyetine Etkisi: Fethiye Yeşilüzümlü ve Yöresi Kuzugöbeği Mantar Festivali Örneği, Journal of Tourism and Gastronomy Studies, 5 (2): 28-36.

Bentler, P. M., ve Bonett, D. (1980) Significance Tests and Goodness of Fit in the Analysis of Covariance Structures, Psychological Bulletin, 88 (3): 588-606.

Bilgili, B., Yağmur, Ö. ve Yazarkan, H. (2012). Turistik Ürün Olarak Festivallerin Etkinlik ve Verimliliği Üzerine Bir Araştırma (Erzurum-Oltu Kırdağ Festivali Örneği), Uluslararası Sosyal ve Ekonomik Bilimler Dergisi, 2 (2): 117-124.

Bitner, M. J., Booms, B. H., \& Mohr, L. A. (1994). Critical service encounters: The employee's viewpoint, Journal of Marketing, 58: 95-106.

Carmichael, A. B. (2005). Understanding The Wine Tourism Experience For Winery 200 Visitors İn The Niagara Region, Ontario, Canada, Tourism Geographiex, 7(2): 185-204.

Chang, J. (2006). Segmenting Tourists to Aboriginal Cultural Festivals: An Example in the Rukai Tribal Area, Taiwan, Tourism Management, 27 (6): 1224-1234.

Cole, S. T. ve Chancellor, H. C. (2009). Examining the Festival Attributes that Impact Visitor Experience, Satisfaction and Re-Visit Intention, Journal of Vacation Marketing, 15: 323-333.

Cortina, J. M. (1993). What is Coefficient Alpha?, An Examination of Theory and Applications, Journal of Applied Psychology, 78: 98-104.

Crompton, L. J. ve McKay, L. S. (1997). Motives of Visitors Attending Festival Events, Annals of Tourism Research, 24 (2): 425-439.

Demirbilek, E., Şengül, S. ve Akoğlu, A. (2018). “Turizm Ürünü Olarak Gastronomi Festivalleri (Marmara Bölgesi Örneği)", (Bildiri) Uluslararası Gastronomi Turizmi Araştırmaları Kongresi (Bildiri), Kocaeli Üniversitesi, Kocaeli.

Doğdubay M., Sarıoğlan M. ve Saatçi G. (2011). Destinasyon Pazarlamasında Yerel Yönetimlerin Gastronomik Öğeleri Kullanma Eğilimlerinin Ölçülmesine Yönelik Bir Araştırma (Bildiri). V. Ulusal Gastronomi Sempozyumu, Antalya.

Duran, E., Hamarat, B. ve Özkul, E. (2014). A Sustainable Festival Management Model: The Case of International Troia Festival, International Journal of Culture Tourism and Hospitality Research, 8 (2): 173-193.

Hu, Y. (2010). An Exploration of the Relationships between Festival Expenditures, Motivations, and Food Involvement among Food Festival Visitors. (Doctoral dissertation, Waterloo, Ontario, Canada).

Kargiglioğlu, Ş. ve Kabacık, M. (2017). Gastronomi Turizmi Kapsamında Urla Enginar Festivaline Gelen Turistlerin Festival Hakkındaki Görüşleri, Journal of Tourism and Gastronomy Studies, 5 (3): 409-421

Kim, H., Borges, M., ve Chon, J. (2006). Impacts Of Environmental Values On Tourism Motivation: The Case Of FICA, Brazil, Tourism Management, 27: 957-967. 
Kim, Y. G., Eves, A. ve Scarles, C. (2009). Building a Model of Local Food Consumption on Trips and Holidays: A Grounded Theory Approach, International Journal of Hospitality Management, 28 (3): 423-431.

Kim, Y. G., Suh, B. W. ve Eves, A. (2010). The Relationships Between FoodRelated Personality Traits, Satisfaction, And Loyalty Among Visitors Attending Food Events and Festivals, International Journal of Hospitality Management, 29 (2): 216-226.

Knutson, B. (1988). Frequent Travelers: Making Them Happy and Bringing Them Back, The Cornell Hotel and Resteuroll Administration Quarcerly, 29 (1): 83-87.

LeBlanc, G. (1992). Factors Effecting Customer Evaluation of Service Quality of Travel Agencies: An Invastigation of Customer Perceptions, Journal of Travel Research, 30 (4): 10-16.

Lee, C., Lee, Y. ve Wicks, B. (2004). Segmentation of Festival Motivation by Nationality and Satisfaction, Tourism Management, 25: 61-70.

Lee, S. ve Arcodia, C. (2011). The Role of Regional Food Festivals for Destination Branding, International Journal of Tourism Research, 13 (4): 355-367.

Lee, S. Y., Petrick, J. F., ve Crompton, J. (2007). The Roles of Quality and Intermediary Constructs in Determining Festival Attendees' Behavioral Intention, Journal of Travel Research, 45 (4): 402 412.

Lee, Y. vd. (2008). Festivalscapes and Patrons Emotions, Satisfaction, and Loyalty, Journal of Business Research, 61: 56-64.

Lewis, R. C. (1987). The Measurement of Gaps in the Quality of Hotel Services, International Journal of Hospitality Management, 6 (2): 83-88.

Marangoz, M. ve Biber L. (2007). Kurumsal İmajın ve Kurumsal Ürün Müşteri Bağlılığına Etkileri Karamanoğlu Mehmetbey Üniversitesi Sosyal ve Ekonomik Araştırmalar Dergisi 2: 173-193.

Markovic, S. S., Dorcic, J. ve Krnetic, M. (2015). Visitor Satisfaction and Loyalty Measurement of a Local Food Festival: Application of Festperf Scale, Tourism in Southern and Eastern Europe, 3: 183-196.

Mason, C. M. ve Paggiaro, A. (2012). Investigating the Role of Festivalscape in Culinary Tourism: The Case of Food and Wine Events, Tourism Management, 33: 1329-1336.

Okumuş, B., Okumuş, F. ve McKercher, B. (2007). Turizm destinasyonlarının pazarlanmasında yerel ve uluslararası mutfakların birleşimi: Hong Kong ve Türkiye örnekleri, Tourism Management, 28: 253-261.

Organ, K. vd. (2015). Festivals as Agents for Behaviour Change: A Study of Food Festival Engagement and Subsequent Food Choices, Tourism Management, 48: 84-99.

Özdemir, G. ve Çulha, O. (2009). Satisfaction and Loyalty of Festival Visitors, Anatolia: An International Journal of Tourism and Hospitality Research, 20 (2): 359-373.

Özkan, E., Curkan, S. C. ve Sarak, E. C. (2015). Festivallerin Katılan Ziyaretçiler Üzerine Etkileri: Alaçatı Ot Festivali Örneği, GÜSBEED, 6 (14): 59-69.

Personel, Türk Dil Kurumu (2020) https://sozluk.gov.tr/

Plummer, R. vd (2005). Beer tourism in Canada along the Waterloo-Wellington Ale Trail, Tourism Management, 26 (3): 447-458. 
Schumacker, R. E. (2006). Conducting Specification Searches With Amos. Structural Equation Modeling, A Multidisciplinary Journal, 13 (1): 118- 129.

Schumacker, R. E. ve Lomax, R. G. (2004). A Beginner's Guide to Structural Equation Modeling. Second Edition. Mahwah, NJ: Lawrence Erlbaum Associates.

Sert A.N. (2017). Yerel Halkın Festivallerin Başarı Faktörlerini Algılamalarına Yönelik Bir Çalışma: Beypazarı Örneği Türk Turizm Araştırmaları Dergisi, 1 (2): 29-44.

Sudhahar, C. vd. (2006), Service Loyalty Measurement Scale: A Reliability Assesment, American Journal of Applied Sciences, 3: 4.

Şengül, S. (2015). Ege Bölgesi Mutfak Kültürü ve Yöresel Yemekleri, İçinde: S. Şengül, A. Çakır ve G. Çakır (Editörler), Yöresel Mutfaklar. (ss. 73-94). Ankara: Beta Basım Yayım

Thompson, K. ve Schofield, P. (2009). Segmenting and Profiling Visitors to the Ulaanbaatar Naadam Festival by Motivation, Event Management, 13 (1): 1-15.

Thrane, C. (2002). Music Quality, Satisfaction, and Behavioral Intentions Within a Jazz Festival Context. Event Management, 7 (3): 143-150.

Wan, Y. K. P. ve Chan, S. H. J. (2013). Factors that Affect the Levels of 1. Tourists' Satisfaction and Loyalty towards Food Festivals: a Case Study of Macau, International Journal of Tourism Research, 15: 226-240.

Wolf, E. (2006). Culinary Tourism the Hidden Harvest. Abd- Lowa: Kendall/Hunt Publishing Company.

World Tourism Organization, (2012). Global Report on Food Tourism:Madrid,http://cf.cdn.unwto.org/sites/all/files/docpdf/amreports4foodtourism.pdf/, Erişim tarihi: 21 Haziran 2018.

Yılmaz, Ö. (2014). İlişkisel Pazarlama Faaliyetlerinin A ̆̆ızdan A ğıza İletişim (WOM) Yaratma Üzerine Etkisi: Bankacılık Sektörüne İlişkin Bir Alan Araştırması (Doktora Tezi, Balıkesir Üniversitesi Sosyal Bilimler Enstitüsü, Balıkesir).

Yılmaz, Ö. (2016). Bankacılıkta İlişkisel Pazarlama Faaliyetlerinin, Tekrar Satın Alma Niyeti Üzerine Etkisinde İlişkisel Kalite Algısının Aracılık Rolü Üzerine Bir Araştırma. Business $\mathcal{E}$ Management Studies: An International Journal, 4 (2): 142-161.

Yolal, M., Çetinel, F. ve Uysal, M. (2009). An Examination of Festival Motivation and Perceived Benefits Relationship: Eskişehir International Festival, Journal of Convention and Event Tourism, 10 (4): 276-291.

Yoon, Y., Lee, J. ve Lee, C. (2010). Measuring Festival Quality and Value Affecting Visitors' Satisfaction and Loyalty Using a Structural Approach, International Journal of Hospitality Management, 29: 335-342.

Yuan, J. vd. (2005). An Analysis of Wine Festival Attendees' Motivations: A Synergy of Wine, Travel and Special Events?, Journal of Vacation Marketing, 11 (1): 41-58.

Yuan, J. ve Jang, S. (2008). The Effects of Quality and Satisfaction on Awareness and Behavioral Intentions: Exploring The Role of a Wine Festival, Journal of Travel Research, 46 (3): 279-288. 